\title{
Empirical Testing of the Impact of Gender and Marital Status on the Price and Trend of Urban Real Estate - Evidence from Provincial Panel Data of China
}

\author{
$\operatorname{Min} \operatorname{Tan}^{1} \&$ Yajie Bai ${ }^{1}$ \\ ${ }^{1}$ SHU-UTS SILC Business School, Shanghai University, China \\ Correspondence: Yajie Bai, SHU-UTS SILC Business School, Shanghai University, 20 Chengzhong Road, \\ Jiading District, Shanghai 201899, China.
}

Received: April 12, 2018

Accepted: May 11, 2018

Online Published: May 30, 2018

doi:10.5539/ijef.v10n7p38

URL: https://doi.org/10.5539/ijef.v10n7p38

\begin{abstract}
This paper investigates the impact of demographic structure, especially gender and marital status, on the price of regional real estate. This paper utilizes controlled-heteroskedasticity fixed-effect model for the empirical tests based on a panel data set of 30 Chinese provinces from 2011 to 2015. Empirical results show that the gender ratio in the provincial panel data does have a significant negative impact on the regional real estate prices, which implies that when the number of women in a region increases, the real estate price in this region tends to rise. The impact of marital status on the real estate price is not significant according to empirical results.
\end{abstract}

Keywords: demographic structure, gender ratio, marital status, real estate price

\section{Introduction}

The development of China's real estate industry started from the 1980s. Since China started the reform of the monetized housing system in 1998, the national economy has been growing at a rate of $7 \%-8 \%$ annually. At the same time, the commercial housing turnover rate witnessed a $30 \%$ annual growth rate. With the rapid economic development, the deepening reform of the housing system in China, the acceleration of urbanization and the continuous expansion of housing demand, the development of China's real estate industry has entered an unprecedented period of prosperity in recent years. It has gradually developed into a leading industry that supports the national economy. Thus, the fluctuation of housing prices has a significant impact on the fluctuation of macroeconomic development.

Nevertheless, problems, such as huge price differences, large price float in China's real estate industry etc. do exist. However, those problems provide investors with excellent investment opportunities. According to statistics from China National Bureau of Statistics, the proportion of China's real estate investment in fixed asset investment has rapidly risen from 5.6\% in 1990 to more than $20 \%$ in 2010 . The real estate industry has become the direct lifeline of China's economy and the major field pursued by global investors. Therefore, it is imperative to study the influencing factors of price and the trend of real estate in China. On the one hand, it can help investors make rational investments. On the other hand, it can help judge potential problems in this industry through observation of price movements, which can help to carry out proper intervention policies or economic regulation. Moreover, it provides suggestion for the public to conduct self-analysis of real estate prices from a micro aspect so that they may reduce unnecessary loss in investment.

Factors that affect real estate prices are diverse. Some well-known factors include policy control, location conditions, educational resources, population density, business environment etc.. Based on previous research, this paper utilizes the latest data of provincial real estate prices from 2010 to 2015, and comprehensively studies the impact of influencing factors on regional real estate prices. This paper particularly focuses on the effect of gender and marital status.

\section{Related Literature}

The utility price theory of Klau (1986) defines the real estate price as the monetary performance of the utility, relative rarity and the effective demand. From the definition, the influencing factors of the real estate price are very complex, and any seemingly unrelated factors may directly or indirectly lead to abnormal fluctuation of 
housing prices. Therefore, it is very difficult to make thorough regulation and control. This is also the main reason why China's housing prices unexpectedly continue to rise despite strict regulation.

A great deal of previous literature pertains to differences in fluctuation of regional real estate prices. Downs (1993) finds that the fluctuation of regional real estate prices is mainly due to differences in regional market conditions. For example, in some regions, there are rapidly growing large enterprises or fast-growing population. Therefore, compared with a relatively static market, the real estate price of a dynamic market is associated with more frequent and more intense fluctuation. Rady (2004) studies the relationship between housing transaction volume and macroeconomic fluctuation in United Kingdom. It is believed that in 1980s, the liberalization of world finance and the relative changes in the population environment have a significant impact on real estate prices and the volume of transaction. On this basis, the conclusion is that the fluctuation of the demand for housing is the key factor that affects abnormal fluctuation in real estate prices. Cao and Liu (2007) classify the main factors that affect the real estate price in China in five aspects: transaction price of land, real estate demand, interest rate of bank loans, rental price of housing, and demolition policies.

Weil (1992) explores the relationship between population and housing demand by building a theoretical function. The age structure of the population is set as a dummy variable to construct a function of age for housing demand. It is found that the age of 20-30 is the phase of greatest demand for housing, and this demand plummets when the age reaches 50. Therefore, the structure of population has a significant impact on the real estate price. Robort (2008) argues that demographic factors help predict the future price movement of the real estate industry. Zhao (2002) argues that the peak of China's population promotes the demand of real estate, and the real estate price increased during this period. Du and Zhang (2011) conducts Grey relational analysis and finds correlation between China's population economy and Housing Sales Price Index (HSPI). The results show that the population determines the housing demand, and there is a positive causal relationship between the quantity of the population and the sales price of housing. However, $\mathrm{Xu}$ and $\mathrm{He}$ (2012) find that there is a negative correlation between the population dependency ratio and housing prices by analyzing panel data from 1997-2008 of OECD countries.

Previous literature has done a very detailed study on how to define and measure the influencing factors of regional real estate prices. However, most of the research only focuses on the financial indicators such as macroeconomy, microeconomy and national financial industry. Although some literature mentions the demographic structures, yet it lacks details of mainland China's condition, and almost all previous research is theoretical analysis or descriptive analysis rather than empirical testing. The importance of population structure is neglected. However, demographic factors are potential influential factors of real estate price in China's economic environment. Therefore, this paper attempts to solve the abovementioned problems by empirically analyzing the impact of demographic factors on China's real estate prices, with a focus on the analysis of the influences of gender and marital status.

\section{Empirical Analysis}

The methodology is designed as follow:

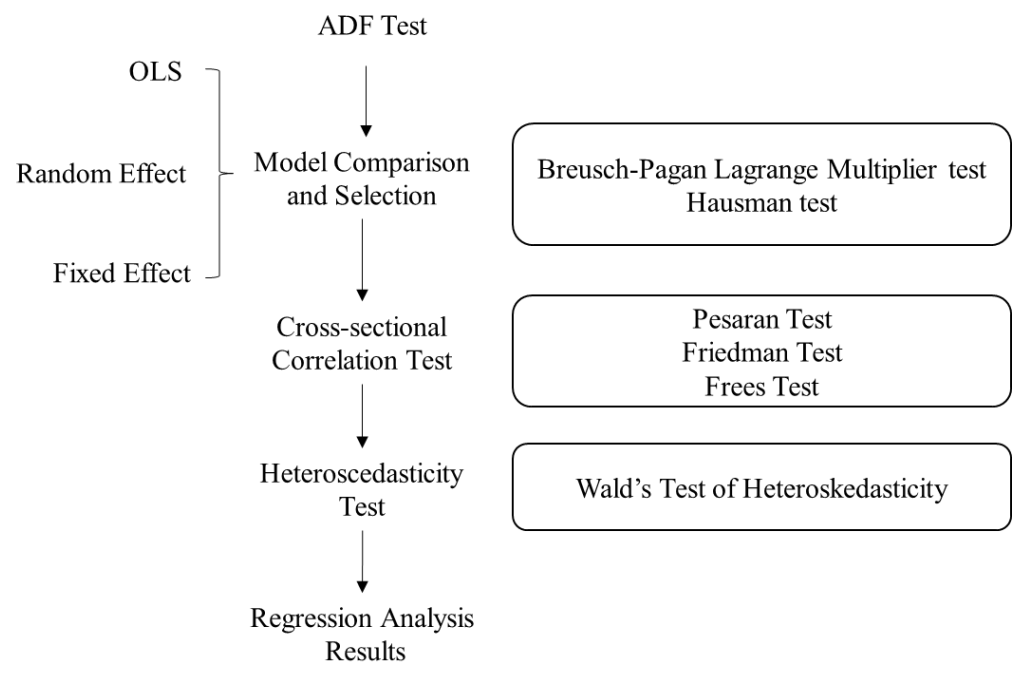

Figure 1. Methodology design 
China has 31 provinces and municipalities directly under the Central Government. After excluding imputed data of Tibet based on its actual economic data, this paper selects data of 30 provinces from 2011-2015, giving a total of 150 observations. Table 1 summarizes details of the explained variable, i.e., the price of real estate during 2011-2015.

Table 1. Real estate price and increase during 2011-2015

\begin{tabular}{|c|c|c|c|c|c|c|}
\hline & 2011 & 2012 & 2013 & 2014 & 2015 & 5-Year Increase \\
\hline Beijing & 16851.95 & 17021.63 & 18553 & 18833 & 22633 & 0.051 \\
\hline Tianjin & 8744.77 & 8217.67 & 8746 & 9219 & 10107 & 0.027 \\
\hline Hebei & 3982.85 & 4478.02 & 4897 & 5131 & 5759 & 0.062 \\
\hline Shanxi & 3432.71 & 3871.38 & 4433 & 4734 & 4870 & 0.059 \\
\hline Inner Mongolia & 3782.93 & 4053.05 & 4301 & 4333 & 4441 & 0.030 \\
\hline Liaoning & 4632.65 & 4942.01 & 5122 & 5373 & 5958 & 0.045 \\
\hline Jilin & 4363.89 & 4146.7 & 4483 & 5112 & 5476 & 0.041 \\
\hline Heilongjiang & 3966.4 & 4067.17 & 4738 & 4882 & 5144 & 0.048 \\
\hline Shanghai & 14603.24 & 14061.37 & 16420 & 16787 & 20949 & 0.061 \\
\hline Jiangsu & 6554.41 & 6726.78 & 6909 & 7006 & 7356 & 0.022 \\
\hline Zhejiang & 9838.06 & 10642.58 & 11042 & 10526 & 10525 & 0.013 \\
\hline Anhui & 4776.1 & 4824.95 & 5080 & 5394 & 5457 & 0.025 \\
\hline Fujian & 7764.29 & 8646.05 & 9050 & 9136 & 8881 & 0.025 \\
\hline Jiangxi & 4147.7 & 4744.66 & 5203 & 5288 & 5358 & 0.045 \\
\hline Shandong & 4447.73 & 4763.01 & 5049 & 5315 & 5560 & 0.040 \\
\hline Henan & 3500.8 & 3831.23 & 4205 & 4366 & 4611 & 0.048 \\
\hline Hubei & 4486.39 & 5042.79 & 5266 & 5513 & 5863 & 0.047 \\
\hline Hunan & 3790.26 & 4048.62 & 4243 & 4227 & 4304 & 0.024 \\
\hline Guangdong & 7879.17 & 8112.19 & 9090 & 9083 & 9796 & 0.039 \\
\hline Guangxi & 3772.47 & 4203.42 & 4593 & 4854 & 4960 & 0.048 \\
\hline Hainan & 8943.45 & 7893.8 & 8669 & 9315 & 9339 & 0.008 \\
\hline Chongqing & 4733.84 & 5079.93 & 5569 & 5519 & 5486 & 0.027 \\
\hline Sichuan & 4917.88 & 5448.82 & 5498 & 5597 & 5475 & 0.020 \\
\hline Guizhou & 3888.78 & 4115.67 & 4295 & 4312 & 4415 & 0.024 \\
\hline Yunnan & 3635.38 & 4209.19 & 4494 & 4998 & 5300 & 0.063 \\
\hline Shaanxi & 4949.2 & 5155.88 & 5280 & 5166 & 5362 & 0.015 \\
\hline Gansu & 3318.24 & 3570.15 & 3886 & 4544 & 4913 & 0.065 \\
\hline Qinghai & 3248.08 & 4048.54 & 4163 & 5081 & 5242 & 0.076 \\
\hline Ningxia & 3732.19 & 3947.88 & 4232 & 4117 & 4413 & 0.031 \\
\hline Xinjiang & 3548.79 & 3918.4 & 4268 & 4628 & 4653 & 0.047 \\
\hline
\end{tabular}

Source: China National Bureau of Statistics.

This paper empirically tests the impact of gender ratio (people aged no less than 15 , female $=100$ ), marital status (people aged no less than 15), population growth rate, total population at the end of the year, old age rate, per capita disposable income, real estate construction area, completed real estate area, population aged over 65 etc.

1) Gender ratio (female $=100$ ). The gender ratio is a problem that is studied at the population level. It refers to the ratio of male to female in the ethnic group. Normally, the demographic gender ratio of male to female is based on the number of males per 100 females. The current ratio of world population is about 105:100.

2) Marital status. The traditional marital status is mainly divided into four categories: married, single, remarried, and divorced. In order to simplify the analysis, this paper selects men and women over the age of 15 in the region and merges explanatory variables into married rate (also includes divorce and remarriage) and single rate of males and females over the age of 15 in the region. Based on that, this paper compares the growth rate of regional housing prices to draw corresponding conclusion.

3) Population growth rate. The population growth rate is the ratio of population growth to total population over a period of time in the region (the period in this paper is one year). In this paper, population growth only includes natural population growth and the population growth rate is the net growth rate.

4) Total population at the end of the year. Total population refers to the total number of people with life 
activities within a certain time and place. It has nothing to do with gender, age, race, religion etc. As long as an individual has an independent life activity, he or she is counted in the total population. The total population is the most basic indicator of the population statistics, especially in densely populated China. The impact of this indicator on housing prices cannot be neglected.

5) Old age rate. It is expressed by the ratio of the growth rate of the elderly population to the growth rate of the total population. This variable compares and observes the growth rate of the elderly population in the total population. When the ratio is greater than 1 , it means that the population of the elderly grows faster than the total population. Under this circumstance, the degree of aging deepens. However, if the ratio is less than 1, it means that the growth rate of the elderly is slower than the total population. This situation means that the degree of aging is predicted to slow down. This paper reckons that aging is also an important part of the demographic structure. So, old age rate is analyzed.

6) Per capita disposable income. Per capita disposable income is used in real life to refer to disposable income per capita. People's disposable income is the sum of people's final consumption expenditures and savings. People's disposable income is considered to be the most important determinant of consumer spending and is therefore often used to measure changes in the living standards of a country. A great deal of previous literature finds that per capita disposable income is a key factor affecting real estate prices. This paper posits that this variable also has a direct relationship with the increase in real estate prices.

7) Real estate construction area. The real estate construction area includes the completed real estate in the current period, and also, area suspended after the construction period. For a multi-storeyed building, the construction area includes the total building area of each floor.

8) Completed real estate area. The completed real estate area refers to the total area of a house that meets the requirement of living and use. Completed real estate area has to be verified by an official organization (or the completion acceptance criteria are met).

9) Unemployment rate. Unemployment rate refers to the ratio of the number of still-unemployed laborers in the employment population that satisfies all employment conditions in a given period of time. It is designed to measure labor productivity in idleness. It is a major indicator of unemployment in a country or region. This paper hypothesizes that the unemployment rate also directly affects the price of real estate.

10) Population aged over 65 years old. This variable refers to the elderly population in the region.

Emphatically, this paper analyzes the impact of gender ratio and marital status on real estate sales prices. Descriptive statistics of all variables are shown in Table 2.

Table 2. Descriptive statistics of variables

\begin{tabular}{cccccc}
\hline Variables & No. & Mean & Std. Err. & Min. & Max. \\
\hline Average Sales Prices of Housing & 150 & 6338.268 & 3598.71 & 3248.08 & 22633 \\
Gender Ratio (female=100) & 150 & 105.2656 & 4.012963 & 95.77 & 120.43 \\
Male Unmarried Rate & 150 & .2336667 & .0396193 & .15 & .36 \\
Female Unmarried Rate & 150 & .1736 & .0317135 & .12 & .26 \\
Population Growth Rate & 150 & .7168 & .7741853 & -.55 & 4.29 \\
Population & 150 & 4507.84 & 2695.165 & 568 & 10849 \\
Old Age Rate & 150 & 9.4146 & 1.775202 & 5.47 & 14.12 \\
Per Capita Disposable Income & 150 & 25481.92 & 7096.527 & 14988.68 & 52962 \\
Construction Area & 150 & 59421.78 & 469071.7 & 1666.049 & 5763772 \\
Completed Real Estate Area & 150 & 4001.251 & 2733.973 & 262.9567 & 11681.01 \\
Unemployment Rate & 150 & 3.345333 & .645569 & 1.2 & 4.5 \\
Population Over 65 years Old & 150 & 17724.75 & 35309.03 & 288 & 178471 \\
\hline
\end{tabular}

Source: China National Bureau of Statistics.

The data used in this paper is a typical short panel data with $\mathrm{N}=30$ and $\mathrm{T}=5$. In order to avoid spurious regression that may affect the accuracy of the empirical test, this paper first detects unit root of the real estate sales price. The result shows that the selected explained variables and all 11 explanatory variables are stationary series. Based on the Breusch-Pagan Lagrange Multiplier test and the Hausman test, the fixed effect model is found to be better than the OLS and the random effect model in this case. In order to detect cross section correlation, this paper conducts Pesaran test, Friedman test, and Frees test. All three methods find that the data 
do not have cross section correlation, which means that fixed effect model is feasible. After Wald's test of heteroskedasticity, the data used in this paper show a very significant presence of heteroskedasticity. At the same time, because the 5-year short-panel data do not need serial correlation test, this paper utilizes the fixed-effect model that controls heteroskedasticity as the most appropriate regression model.

The regression results are shown in Table 3. Regression I is ordinary least square (OLS) regression that controls heteroskedasticity. Regression II is panel data fixed effect regression that controls heteroskedasticity. Regression III is pooled OLS. Regression IV is asymptotic panel data fixed effect model that controls heteroskedasticity. Regression V is panel data error correction standard error (PCSE) regression. This paper interprets results of Regression II (panel data fixed effect model that controls heteroskedasticity), which is esteemed to be the best model in this case.

Table 3. Real estate sales price regression results and robustness check

\begin{tabular}{|c|c|c|c|c|c|}
\hline \multirow[b]{2}{*}{ Explanatory Variables } & \multicolumn{5}{|c|}{ Explained Variables: Real Estate Sales Price } \\
\hline & $\begin{array}{c}\text { Reg I } \\
\text { Coefficient } \\
\text { (Std. Err) } \\
\end{array}$ & $\begin{array}{c}\text { Reg II } \\
\text { Coefficient } \\
\text { (Std. Err) } \\
\end{array}$ & $\begin{array}{c}\text { Reg III } \\
\text { Coefficient } \\
\text { (Std. Err) } \\
\end{array}$ & $\begin{array}{c}\text { Reg IV } \\
\text { Coefficient } \\
\text { (Std. Err) }\end{array}$ & $\begin{array}{c}\text { Reg V } \\
\text { Coefficient } \\
\text { (Std. Err) } \\
\end{array}$ \\
\hline Gender Ratio (GR) & $\begin{array}{l}39.19 \\
(0.97)\end{array}$ & $\begin{array}{l}\mathbf{- 2 0 . 6 8}^{* *} \\
(-2.13)\end{array}$ & $\begin{array}{l}-20.68 \\
(-1.80)\end{array}$ & $\begin{array}{l}39.19 \\
(1.56)\end{array}$ & $\begin{array}{l}39.19 \\
(1.41)\end{array}$ \\
\hline $\begin{array}{l}\text { Unmarried Male Percentage } \\
\text { (UM) }\end{array}$ & $\begin{array}{c}-8429.1 \\
(-1.19)\end{array}$ & $\begin{array}{l}-2330.6 \\
(-1.33)\end{array}$ & $\begin{array}{l}-2330.6 \\
(-1.11)\end{array}$ & $\begin{array}{r}-8429.1 \\
(-2.14)\end{array}$ & $\begin{array}{l}-8429.1 \\
(-1.42)\end{array}$ \\
\hline $\begin{array}{l}\text { Unmarried Female Percentage } \\
\text { (UF) }\end{array}$ & $\begin{array}{c}26010.5^{* * *} \\
(3.67)\end{array}$ & $\begin{array}{l}392.9 \\
(0.16)\end{array}$ & $\begin{array}{l}392.9 \\
(0.18)\end{array}$ & $\begin{array}{c}26010.5^{* * *} \\
(5.86)\end{array}$ & $\begin{array}{c}26010.5^{* * *} \\
(4.01)\end{array}$ \\
\hline Construction Area (CA) & $\begin{array}{c}-0.000343^{* * *} \\
(-5.50)\end{array}$ & $\begin{array}{c}-\mathbf{0 . 0 0 0 0 6 0 1 * * *} \\
(-3.63)\end{array}$ & $\begin{array}{c}-0.0000601 \\
(-1.69)\end{array}$ & $\begin{array}{c}-0.000343^{* * *} \\
(-6.78)\end{array}$ & $\begin{array}{c}-0.000343^{* *} \\
(-2.34)\end{array}$ \\
\hline $\begin{array}{l}\text { Completed Real Estate Area } \\
\text { (CREA) }\end{array}$ & $\begin{array}{c}-0.247^{* * * *} \\
(-2.91)\end{array}$ & $\begin{array}{c}\mathbf{0 . 0 7 7 3} * \\
(2.74)\end{array}$ & $\begin{array}{c}0.0773 \\
(0.84)\end{array}$ & $\begin{array}{l}-0.247^{* * *} \\
(-17.95)\end{array}$ & $\begin{array}{c}-0.247^{* * *} \\
(-2.80)\end{array}$ \\
\hline $\begin{array}{l}\text { Per Capita Disposable Income } \\
\text { (PCDI) }\end{array}$ & $\begin{array}{l}0.400^{* * *} \\
(12.00)\end{array}$ & $\begin{array}{c}\mathbf{0 . 1 2 3} \\
(5.61)\end{array}$ & $\begin{array}{l}0.123^{* * *} \\
(22.35)\end{array}$ & $\begin{array}{l}0.400^{* * *} \\
(15.85)\end{array}$ & $\begin{array}{l}0.400^{* * *} \\
(14.31)\end{array}$ \\
\hline Unemployment Rate (UR) & $\begin{array}{c}-1028.4^{* * *} \\
(-2.72)\end{array}$ & $\begin{array}{l}105.9 \\
(0.45)\end{array}$ & $\begin{array}{l}105.9 \\
(0.68)\end{array}$ & $\begin{array}{c}-1028.4^{* * *} \\
(-5.84)\end{array}$ & $\begin{array}{c}-1028.4^{* * * *} \\
(-4.95)\end{array}$ \\
\hline Total Population (TP) & $\begin{array}{c}0.0604 \\
(0.80)\end{array}$ & $\begin{array}{c}1.719^{* * *} \\
(4.43)\end{array}$ & $\begin{array}{l}1.719 \\
(0.91)\end{array}$ & $\begin{array}{l}0.0604 \\
(1.72)\end{array}$ & $\begin{array}{l}0.0604 \\
(0.66)\end{array}$ \\
\hline $\begin{array}{c}\text { Population Growth Rate } \\
\text { (PGR) }\end{array}$ & $\begin{array}{l}105.0 \\
(0.46)\end{array}$ & $\begin{array}{l}\mathbf{- 5 9 2 . 2 ^ { * * }} \\
(-2.47)\end{array}$ & $\begin{array}{l}-592.2^{* * *} \\
(-10.63)\end{array}$ & $\begin{array}{l}105.0 \\
(0.72)\end{array}$ & $\begin{array}{l}105.0 \\
(0.63)\end{array}$ \\
\hline $\begin{array}{l}\text { Population over } 65 \text { Years Old } \\
\qquad(\mathrm{P} 65)\end{array}$ & $\begin{array}{c}-0.0158^{* * *} \\
(-4.32)\end{array}$ & $\begin{array}{c}-0.00184 \\
(-1.68)\end{array}$ & $\begin{array}{c}-0.00184 \\
(-2.13)\end{array}$ & $\begin{array}{c}-0.0158^{* * *} \\
(-7.37)\end{array}$ & $\begin{array}{c}-0.0158^{* * *} \\
(-2.72)\end{array}$ \\
\hline Old Age Rate (OAR) & $\begin{array}{l}201.3^{* *} \\
(2.17)\end{array}$ & $\begin{array}{l}130.8 \\
(1.04)\end{array}$ & $\begin{array}{l}130.8 \\
(1.29)\end{array}$ & $\begin{array}{l}201.3^{* * *} \\
(5.85)\end{array}$ & $\begin{array}{c}201.3^{* * *} \\
(2.61)\end{array}$ \\
\hline _CONS & $\begin{array}{l}-8034.9^{*} \\
(-1.78)\end{array}$ & $\begin{array}{c}-3316.9 \\
(-0.46)\end{array}$ & $\begin{array}{c}-3316.9 \\
(-1.50) \\
\end{array}$ & $\begin{array}{r}-8034.9 \\
(-2.10)\end{array}$ & $\begin{array}{c}-8034.9^{* *} \\
(-2.27)\end{array}$ \\
\hline
\end{tabular}

The best fitted model is Regression II, which formulated as follow:

$$
\begin{gathered}
P=-3316.0-20.68 S R-2330.6 U M+392.9 U F-0.0000601 C A+0.0773 R E A+0.123 P C D I+105.9 U R \\
+1.719 T P-592.2 P G R-0.00184 P 65+130.80 A R+\varepsilon
\end{gathered}
$$

Based on the regression results, this paper makes a conclusion about the impact of the sex ratio and marital status on the real estate sales prices. From a gender perspective, there is a negative correlation between the sex ratio (female $=100$ ) and the sales price of real estate at the 5\% significance level, which means that the growth in the number of women can stimulate the growth of real estate sales prices. The reasons for this phenomenon can be explained from the status quo in China, where women are more anxious for a stable living condition and real estate is an important aspect of giving women a sense of security. Meanwhile, real estate is closely related to the important decisions such as job selection and marriage decision in China. Therefore, when the number of women grows faster than the number of men, the overall social demand for real estate is estimated to increase as well. However, the results show that there is no significant correlation between the marital status with real estate sales prices. 
At the same time, the results also show some other information. The construction area of real estate in the region and the disposable income of people are positively correlated with the real estate sales prices, and they are significant at $1 \%$ significance level. The total construction area of real estate can directly reflect the amount of investment in the real estate industry in this region and the growth of investment shows a good prospect and expectation for the development of this industry. Furthermore, the increase of per capital disposable income also stimulates the investment and consumption of real estate. As a result, real estate sales prices are estimated to increase. Moreover, at 5\% significance level, total population and population growth rate are positively correlated with the real estate sales prices; the actual sales area of real estate and real estate sales price in the region have a positive correlation, but only at $10 \%$ significance level. What is more, the impact of the unemployment rate, the proportion of population aged 65 and the old age rate on real estate sales price are not significant.

\section{Conclusion}

The real estate industry has become the leading industry of China's national economy. It is imperative to investigate factors that affect its price. Previous research has put forward theoretical analysis and strategic suggestion on the influence of population structure on real estate prices. However, these theories often neglect the role of gender and marital status in the population structure. Based on data of 30 provinces and cities in China (excluding Tibet) from 2011 to 2015, this paper explores the impact of population structure on the regional real estate sales price through empirical research, and focuses more on the role of gender and marital status. This paper finds that the sex ratio does have a significant negative correlation with the regional real estate sales price under the provincial panel data, which means that when the number of women in a certain area tends to increase, the real estate sales price in the region is predicted to rise. However, the marital status does not have significant impact on the real estate sales price.

Based on the findings, this paper suggests that the government should keep a close eye on changes in population structure and adjust the development strategy of real estate accordingly. In terms of population structure, the government can update the demographic structure and add important factors (such as gender and marital status) which are previously ignored, into the monitor system to make early intervention. Meanwhile, the government is encouraged to promptly release the latest information to the public to facilitate the accuracy of housing prices forecast. For example, when a city experiences dramatic change in sex ratio, the local government should actively regulate it. In addition, due to the generally long construction period of the real estate industry, the government and relevant departments need to improve the forward-looking of data monitoring and take precautions on the adjustment of the scale and the structure of housing supply so as to avoid excessive fluctuation of the sales price of real estate. Moreover, based on the actual circumstances of those cities, government and related department should timely adjust the ratio of urbanization and actively develop the rural economy to slow down the process of urbanization and alleviate the fast increasing of urban housing prices.

However, the research in this paper still has some limitations which need to be considered more in the future. In this research, even the cross-sectional test was implemented to test whether there exists correlation between the data of different regions or not, the correlation between each variable haven't been taken into consideration, which may result in lowering the reliability and validity of the regression. Even if it was proved that the results of this paper have a great significance level, to improve the accuracy, this aspect should be tested carefully in the future research.

\section{References}

Birtchnell, J., Masters, N., \& Deahl, M. (1988). Depression and the physical environment: A study of young married women on a london housing estate. British Journal of Psychiatry the Journal of Mental Science, 153(1), 56. https://doi.org/10.1192/bjp.153.1.56

Downs, A. (1993). Real Estate and Long-Wave Cycles. National Real Estate Investor, 1993-6.

He, S. (2015). The influence of population structure on the fluctuation of urban housing price in China (in Chinese). Foreign Trade, (9), 127-129.

He, W. (2012). Analysis of influencing factors of real estate price based on Spatial Econometrics (in Chinese). Economic Review, (1), 48-56.

Huang, W. C. (2014). Influence of individual housing loans policy on real estate market (in Chinese). Value Engineering, 21 .

Huiying, C. (2015). The change of population structure of China asset price analysis and empirical test on the theory (in Chinese). Economic Theory and Business Management, (10), 35-45. 
Matsuyama, A., Nojima, S., Otake, F., Mizuno, K., \& Sato, K. (2008). The influence of design guide for residential areas townscape on the rebuilding actions of council housing estate: A case study on birmingham city in UK. Journal of the City Planning Institute of Japan, (43), 631-636. https://doi.org/10.11361/journalcpij.43.3.631

Na, G. (2016). Research on the impact of population aging on China's real estate prices (in Chinese). Price Theory and Practice, (5), 93-96.

Na, G., \& Jing, W. (2016). Demographic transition, aging and real estate price fluctuation in China: An Empirical Analysis Based on Provincial Threshold Panel Model (in Chinese). Finance and Economics, (12), $8-13$.

Quigley, J. M. (1999). Real Estate Prices and Economic Cycles. International Real Estate Review, 2(1), 1-20. https://doi.org/10.1159/000067751

Yang, Z. (2016). The influence of population structure on real estate price -- Based on dynamic panel and threshold model (in Chinese). Jilin Financial Research, (3), 13-16.

Yuan, F. (2012). The influence of population structure on the price fluctuation of real estate (in Chinese). Times Finance, (27), 102-104.

\section{Copyrights}

Copyright for this article is retained by the author(s), with first publication rights granted to the journal.

This is an open-access article distributed under the terms and conditions of the Creative Commons Attribution license (http://creativecommons.org/licenses/by/4.0/). 